\title{
Gender Equality: Challenges toward Efforts to Minimize Child Marriage in Indonesia during the Covid-19 Pandemic
}

\author{
Sonny Dewi Judiasih", Nyulistiowati Suryanti, Sudaryat and Deviana Yuanitasari
}

Faculty of Law, Universitas Padjadjaran, Indonesia

\begin{abstract}
The practice of child marriage in Indonesia is a serious problem that must be resolved. This is a problem faced in various countries in the world. The SDG's programs include achieving gender equality and empowering women and girls, with a target to achieve the abolition of child marriage by 2030 . The research method used is a social-legal approach. The purpose of this study is to find out the government's efforts in overcoming the problem of gender inequality in the age requirements for marriage in Indonesia and the application for dispensation for marriage during the Covid-19 pandemic in Indonesia. The old Marriage Law stipulates that the age of marriage for men is 19 years and for women 16 years. The government then changed this provision through Law Number 16 of 2019 concerning Marriage, in which the marriage age for men and women is the same, which is 19 years. During the Covid-19 pandemic, applications for marriage dispensation in Indonesia indicated a sharp increase. This means that the application for marriage dispensation is unaffected by the Covid-19 pandemic situation. The existence of exceptions through dispensation efforts makes the requirements for the age of marriage can still be deviated, so that gender equality, which is expected to minimize child marriages above, cannot be realized or cannot be carried out as desired.
\end{abstract}

Keywords: Child marriage, gender equality, pandemic covid 19.

\section{INTRODUCTION}

Child Marriage or often referred to as minor marriage is a marriage performed by a person whose age has not reached the age specified by the Law. Article 28 B of the 1945 Constitution states that every child has the right to survival, growth and development and the right to protection from violence and discrimination.

Every boy and girl has the same rights. The reality in society, however, especially with regards to child marriage, girls are more often wedded before entering the legal age than boys. As a comparison, child marriage occurrences are 1 in 9 girls and 1 in 100 boys.

From the UNICEF 2018 data, for the last decade, 25 million child marriages can be prevented through a variety of effective efforts. However, 650 million women and girls currently living married before their $18^{\text {th }}$ birthday. Factors that cause the occurrence of child marriage, among others are strong influences from customs, habits and religions, poverty levels in society, geographical location, gender inequality, the impact of disasters, lack of access to reproductive health information and pregnancy outside of marriage.

The illustration above shows that the practice of child marriage occurs in all regions in Indonesia. The percentage in each region is written in the black box.

*Address correspondence to this author at the Faculty of Law, Universitas Padjadjaran, Indonesia; E-mail: sonny@unpad.ac.id

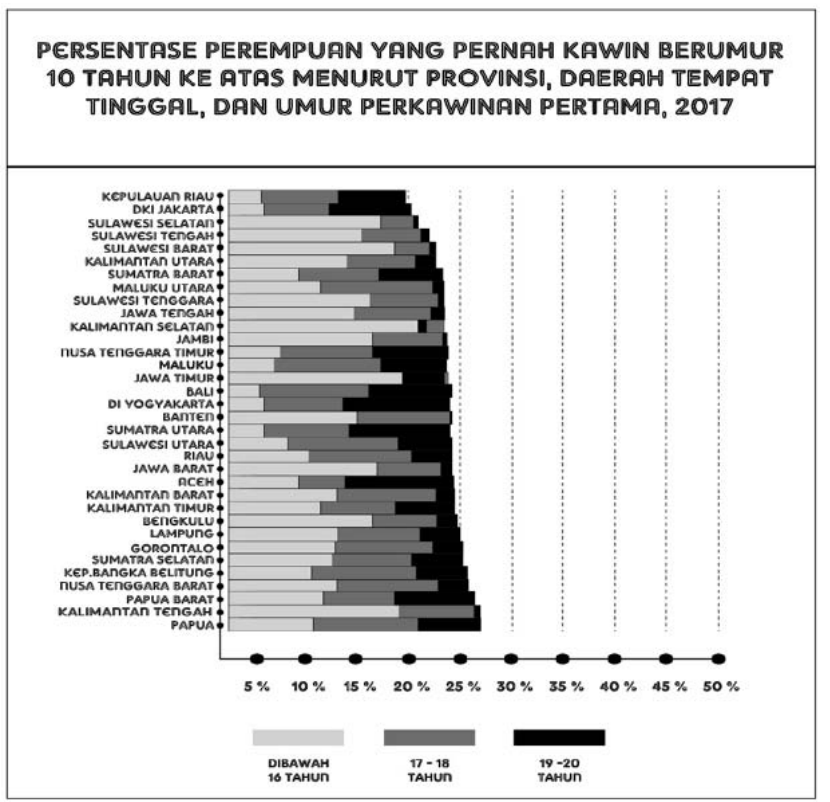

Figure 1: Statistics of Child Marriage in Indonesia (in Percent).

Source: BPS-Statistics Indonesia 2017.

From the figure above, West Java is the region with the highest number of child marriage uccurrences in Indonesia, followed by East Java and Central Java.

With regards to the Practice of Child Marriage, Indonesia is in the $37^{\text {th }}$ in the world and hold the $2^{\text {nd }}$ position in the Southeast Asian Region. The latest data from SUSENAS 2018 shows that in Indonesia, girls marrying before the age of 18 are estimated at $1,220,900$. This causes the Indonesian position to rise to number 8 in the world as a country with most practices of child marriage. 


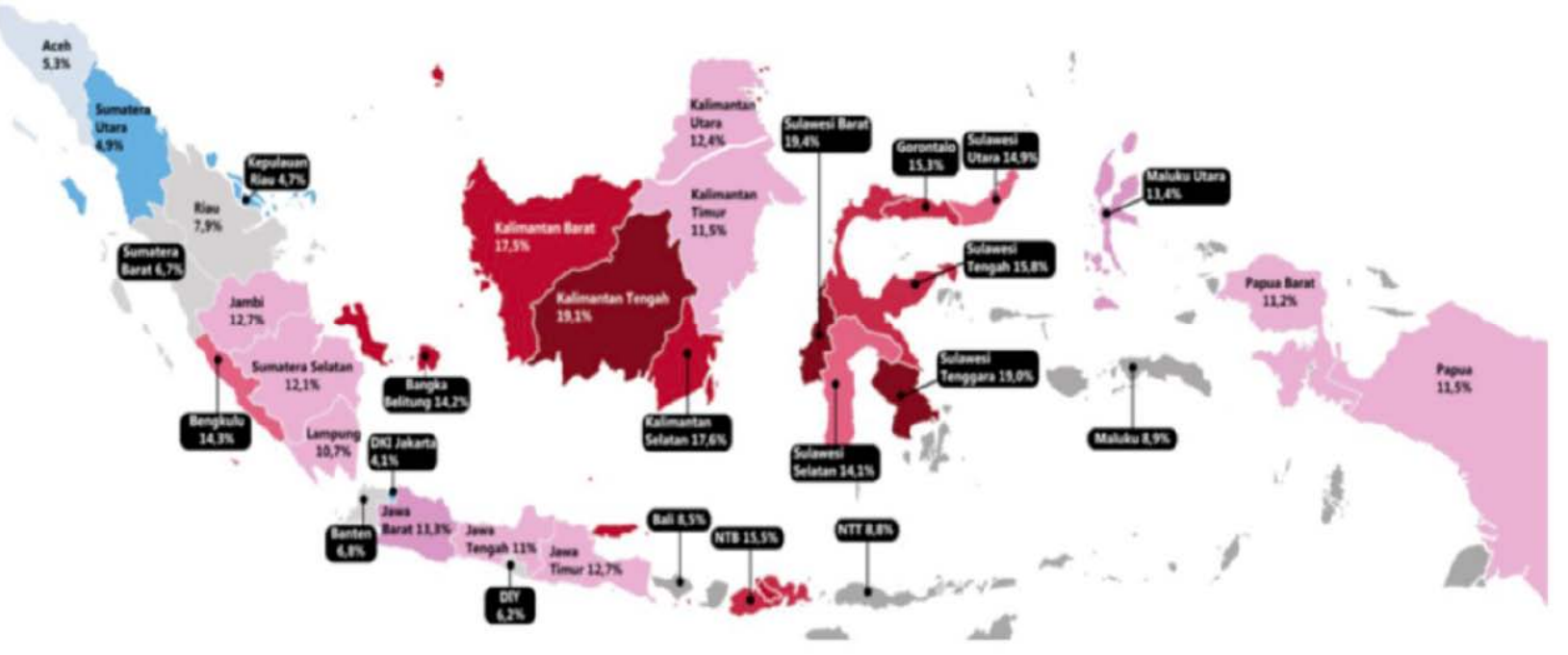

Figure 2: Illustration of Child Marriage Practices in Indonesia. Source: the National Development Planning Agency 2020.

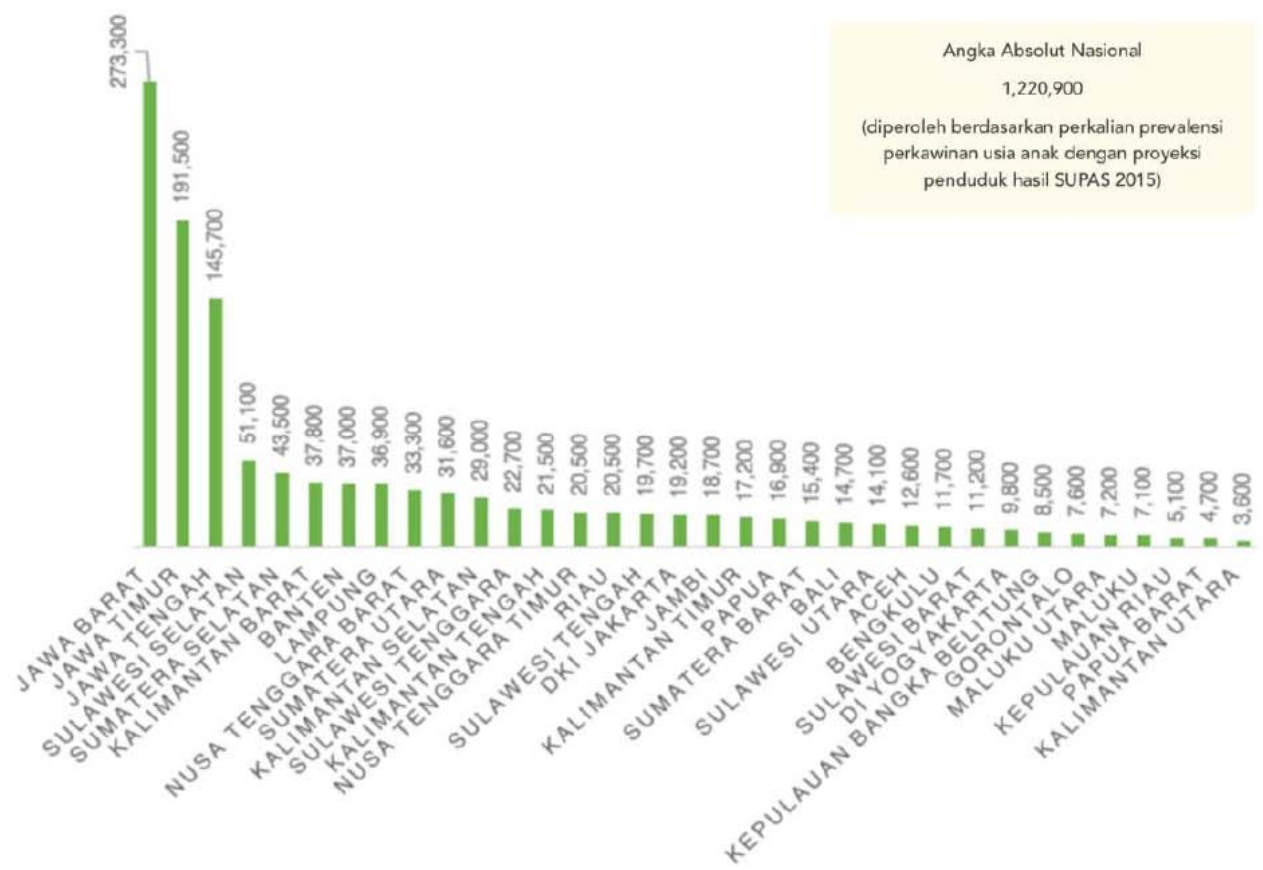

Figure 3: Detail of Absolute Number of Child Marriage in Provinces in Indonesia in 2018.

Source: the National Development Planning Agency 2020.

The Sustainable Development Goals initiated by the United Nations have various objectives as outlined in the following figure:

The goal in point 5 of the SDGs is to achieve gender equality and empower all women and girls. Meanwhile, one of the targets that must be achieved in SDGs point 5.3 is to eliminate all harmful practices, such as child marriage, forced marriage and female genital mutilation. The UN is targeting that by 2030 there will be no more child marriage practices in all regions of the world.

Identification of problems:

1. What are the government's efforts to address the issue of gender inequality in terms of the age of marriage in Indonesia?

2. How is the application for marriage dispensation during the Covid-19 pandemic in Indonesia? 


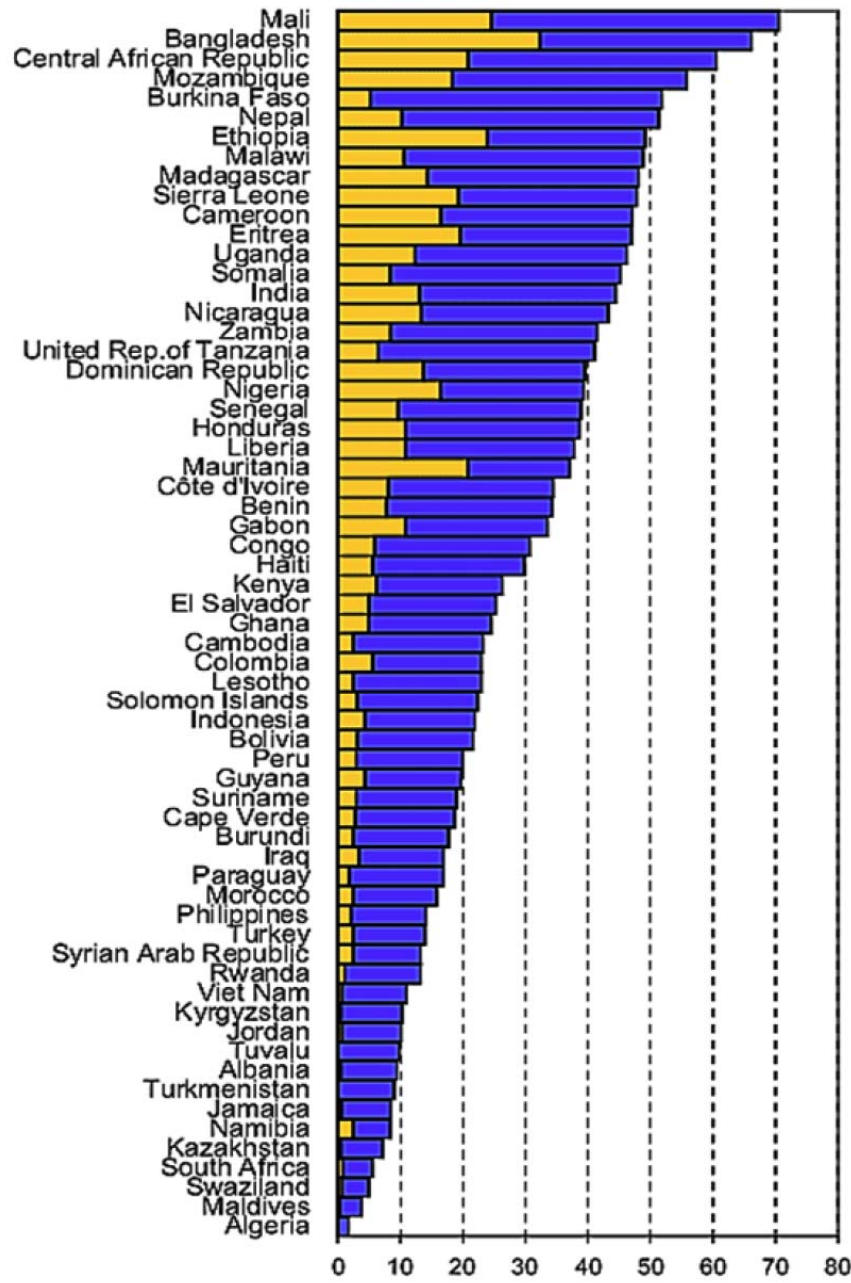

Percentage aged 20-24 who married by age 15 and 18

口Percentage married by age 15 口Percentage married by age 18

Figure 4: Countries with Most Child Marriage Practices.

Source: Measure, ICF Marco 2011.

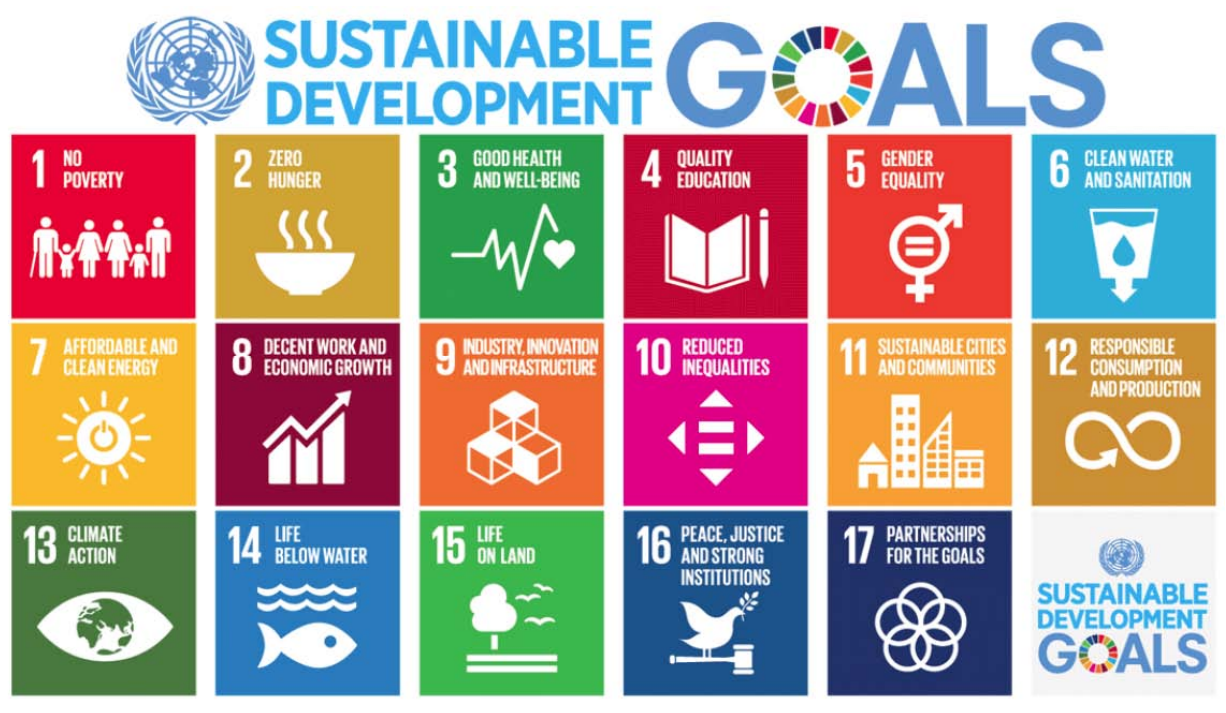

Figure 5: Sustainable Development Goals. 


\section{DISCUSSION}

\section{The Government's Efforts to Address the Issue of Gender Inequality in Terms of the Age of Marriage in Indonesia}

Gender is a cultural concept that seeks to make a distinction in terms of roles, behaviour, mentality, and emotional characteristics between men and women that develop within societal structures. ${ }^{1}$ Gender is also an aspect of social relationships that are associated with sexual differentiation in humans. ${ }^{2}$ The conception of gender itself is related to social differences between men and women. It is said that the behaviour and characteristics that are generally inherent to women and men are not natural. ${ }^{3}$ Differences in social characteristics and behaviour between men and women diverge across cultures and countries. Gender is an important attribute that describes different types of interactions. ${ }^{4}$

Gender, which often leads to social differences between men and women, is one focus of the Sustainable Development Goals (SDGs). Gender equality is considered a critical point to achieve the success of the Sustainable Development Goals. ${ }^{5}$ Gender equality is a concept stating that men and women have equal rights and opportunities in all fields without considering their biological characteristics. ${ }^{6}$ Both men and women have equal rights in their social life. The concept of gender equality states that all people have the same right to develop their personal abilities and skills. ${ }^{7}$ Gender equality is based on fairness and equality for all people regardless of their background. $^{8}$

${ }^{1}$ Azyumardi Azra, 2008, Kajian Tematik Al-Qur'an tentang Kemasyarakatan, Bandung : Angkasa, page 315

${ }^{2}$ Alan Sigit Fibrianto, 2016, Kesetaraan Gender Dalam Lingkup Organisasi Mahasiswa Universitas Sebelas Maret Surakarta Tahun 2016, Jurnal Analisa Sosiologi, Vol 5 No 1, page 13

${ }^{3}$ Bianka Poczatkova \& Pavlina Kribikova, 2017, Gender Inequality In The Field Of Science And Research, Journal Of International Studies, Volume 10 Number 1, page 267

${ }^{4}$ Ewa Bielska, 2015, Gender As A Category Entangled In The Matrix Of Power And Gender Resistance Potential, Journal Of Gender and Power, Volume 3 Number 1, page 107

${ }^{5}$ R.Dhatt, K. Thompson, D. Lichtenstein, K. Ronsin and K.Wilkins, The Time is Now - a Call to Action for Gender Equality in Global Health Leadership, 2017, Global health, Epidemiology and Genomics, Vol 2, page 1

${ }^{6}$ Sonny D Judiasih, Betty Rubiati, Deviana Yuanitasari, Elycia F. Salim, Levana Safira, 2020, Efforts to Eradicate Child Marriage Practices in Indonesia

Towards Sustainable Development Goals, Journal of International Women's Studies, Vol 21, Issue 6, page 142

${ }^{7}$ Anna Odrowaz-Coates, 2015, Is Gender Neutrality A Post Human Phenomenon? The Concept of 'Gender Neutral' in Swedish Education, Journal Of Gender and Power, Volume 3 Number 1, page 268

${ }^{8} \mathrm{Ibid}$, page 123
Gender equality has long been recognized as a human right and a primary goal of development. ${ }^{9}$ The norm of equality, as stated in the provisions of national and international constitutions, is often stated as "equality before the law". It is further expanded by referring to 'equality of legal protection', and involves the existence of a legal system that does not allow discrimination in the substance of the law. Several constitutions and human rights instruments combine these two concepts and link to 'equality before the law and equal legal protection'. ${ }^{10}$

The concept of equality has been strengthened in the discussions of the Committee on Human Rights and the Committee on Economic, Social and Cultural Rights. These developments have contributed to a much more dynamic interpretation of equality in international human rights law that can be utilized to address the diversity and complex manifestations of gender-based discrimination. They acknowledge that all human rights are for all women and the need to conform to universal norms of equality are inseparable from the fulfilment of civil, political and socio-economic rights. ${ }^{11}$ If there is a deficit of human rights aspects in government and law enforcement, socio-economic rights cannot be justified as rights. ${ }^{12}$

In recent years, there has been significant progress on gender and human rights issues in conceptualizing institutional development as an effort to set boundary standards through national and international law as well as jurisprudence. Recently, several national and international human rights institutions have done more than simply include 'women' in their list of 'vulnerable' groups, rather, they have started to include women in recommendations for structural changes needed to fully realize women human rights. ${ }^{13}$

In reality, discrimination or gender inequality still occurs. Gender can be used as a good analytical tool to understand the issue of discrimination against women in general. ${ }^{14}$ Gender talks about the position of men and women, but in social life, this theory is not

\footnotetext{
${ }^{9}$ Carolyn Frohmader \& Stephanie Ortoleva, 2014, The Sexual and Reproductive Rights of Women and Girls With Disabilities, ICPD Beyond, Vol. 1 , page 4

${ }^{10}$ Savitri Goonesekere, 2014, From Social Welfare To Human Rights For Girls - A Path To Achieving Gender Equality, International Journal of Law in Context, Vol. 10 Issue 4 , page 479

${ }^{11} \mathrm{Ibid}$, page 480

${ }^{12} \mathrm{Ibid}$. page 489

${ }^{13}$ Stephanie Ferror, 2009, Human Rights Advocacy on Gender Issues: Challenges and Opportunities, Journal of Human Rights Vol 1 No 1, page 83

${ }^{14}$ Ulfatun Hasanah dan Najahan Musyafak, 2017, Keterlibatan Perempuan dalam Pembangunan Politik, Gender and Politics, Vol 12 No 3, page 415
} 
suitable. The rules on gender discrimination fundamentally regulate discrimination against both men and women, but it is often women who are the victims of gender discrimination. ${ }^{15}$ It can be said that gender discrimination is also based on and influenced by the habits that occur in society. ${ }^{16}$ In addition, gender inequality does not only occur due to traditions and beliefs held by the community but also because of the applicable systems and regulations, resulting in a general understanding in the society that the position of women is lower than men.

The view that the position of women is inferior to men has violated the understanding of equal human rights regardless of gender. Discrimination against women must be eliminated because it is a violation of human rights. The elimination of all forms of discrimination is a major concern of CEDAW (The Convention on the Elimination of All Forms of Discrimination against Women). ${ }^{17}$ Differences in gender-based treatment constitute discrimination that aims to negate or harm the rights of a group. In another sense, there is a human right that has been violated because another group tries to eliminate or reduce it.

In international and regional human rights, it is mandatory that every country facilitates gender equality in their jurisdiction, wherever this discrimination occurs. $^{18}$ This is because, in reality, there is a huge number of women facing problems of gender discrimination at the community level, both in terms of sexual harassment and accessibility to work and education. ${ }^{19}$ In general, women in developing countries are discriminated against more than those in developed countries in various aspects of life. ${ }^{20}$ The discrimination occurs in access to education, occupation, marriage, and to have control in life. All are violations of human rights. Statistically, there are more women who are victims of gender discrimination than men. Hence, the empowerment of women and girls is one of the targets of the Sustainable Development Goals in its Gender Equality goal.

\footnotetext{
${ }^{15}$ Cheryl Lynn Kelsey, 2015, Gender Inequality : Empowering Women, Journal of Legal Issues and Cases in Business, Vol 3, page 1

${ }^{16}$ Andrey Shahstri, 2016, Gender Inequality and Women Discrimination, IOSR Journal of Humanities and Social Science, Vol 19 No 11, page 2

${ }^{17}$ Simone Cusack \& Lisa Pusey, 2013, CEDAW And The Rights To NonDiscrimination And Equality, Melbourne Journal of International Law, Vol. 14, page. 7

${ }^{18}$ Alison Stuart, 2015, Right Freedom of Religion: A Gendered Difference, Journal Of Gender and Power, Volume 3 Number 1, page 26

${ }^{19}$ Fitra Shaumi \& Athaya Aushafina, 2018, Gender Equality Through Sustainable Development Goals: The Case of Timor Leste, Jurnal Global \& Strategis, Volume 12 Number 2, page 81

${ }^{20}$ Seema Jayachandran, 2015, The Roots of Gender Inequality in Developing

Countries, The Annual Review of Economic, Volume 7, 2015, page 69
}

Forms of gender inequality can encourage the practice of child marriage. A number of studies found that countries and societies with high gender inequality practices are countries whose laws and customs exclude girls from decision-making in both economic and political rights, and these countries will have a high tendency of child marriage. ${ }^{21}$ The practise of child marriage is fundamental in gender and social norms that exist in a patriarchal society. ${ }^{22}$ Girls with no education are three times more likely to marry before the age of 18 (eighteen) compared to girls with secondary education or higher. ${ }^{23}$

Child marriage, as a manifestation of gender inequality, can be seen from the limitations of options in their life to determine their choices and rights to education. This is because they will be isolated from social life and become housewives who are obliged to take after their husbands and children, hence, most women tend to be 'forced 'to leave their education; they will get a lower education, which in turn, limits the right to determine their own economy, namely to have a job. ${ }^{24}$ Girls who drop out of school due to marriage will show that they will become completely dependent on their husbands. This legitimizes a gradual loss of ability for women to make choices in life because of their low education. $^{25}$

Globally, child marriage often occurs between girls and men who are much older. Hence, the gap in the age in marriage has created a power imbalance between the spouses. Some studies have shown that girls with much older partners are less likely to have the ability to determine their position in the household. This is because they found it difficult to negotiate with their partner about the relationship. This leaves women with minimal autonomy and independence. ${ }^{26}$ Gender inequality, as previously discussed, of girls marrying older and wealthier men will become a new phenomenon that allows the man, who has a much

\footnotetext{
${ }^{21}$ Lauren Rumble (et.al), 2018, "An Empirical Exploration of Female Child Marriage Determinants in Indonesia, BMC Public Health, Vol 18, No 407, page 2, https://doi.org/10.1186/s12889-018-5313-0.

${ }^{22}$ Kazutaka Sekine \& Marian Ellen Hodgkin, 2017, Effect Of Child Marriage On Girls's School Dropout In Nepal: Analysis Of Data From The Multiple Indicator Cluster Survey 2014, PLoS ONE, Volume 12 Number 7, page 11

${ }^{23}$ Ibid, page 2 .

${ }^{24}$ Almee Arrabide, Shoshana Smolen, Sheyda Joolharzadeh, 2013, Research Paper Child Marriage in South Asia, Center for Reproductiver Rights : New York, page 11

${ }^{25}$ Shamnaz Arifin Mim, 2017, "Effects of Child Marriage on Girls education and Empowerment", Journal of Education and Learning, Vol 11 (1), page 12-13, Doi:10.11591/edulearn.v11i1.5130.

${ }^{26}$ Megan Arthur (et.al), 2017, "Child Marriage Laws Around The World: Minimum Marriage Age, Legal Exceptions, and Gender Disparities", Journal of Women, Politics \& Policy, Vol 39, No 1, page 1, doi: 10.1080/1554477X.2017.1375786.
} 
stronger position, to marry more than 20 women. ${ }^{27}$ Married women with a lower position are at greater risk of experiencing domestic violence. ${ }^{28}$

As previously explained, the form of gender inequality occurs because the laws of the country indirectly facilitate the inequality as what happened in Indonesia. Indonesia is one of the largest multicultural countries in the world. This can be seen from the vast and complex socio-cultural and geographical conditions. ${ }^{29}$ In addition to its broad socio-cultural and geographical conditions, Indonesia consists of a large number of ethnic, cultural, religious groups; this makes Indonesia plural and at the same time, heterogeneous. ${ }^{30}$ Each ethnic group has its own cultural characteristics and in its socio-cultural aspects. The diversity of the Indonesian people oftentimes triggered conflicts and divisions from all sides, including customs, culture, and religion.

This current situation requires people with cultural awareness who are able to communicate these differences. This is because the diverse society has the proclivity to lead to group segmentation, divided structures, weak consensus, prone to conflicts, forced integration, and group domination, which in turn can weaken the communal bond. ${ }^{31}$ In social life, culture and religion are interrelated as they influence each other. Religion and culture certainly do not stand alone, both have a higher close relationship in their dialectics. Religion is a guideline for a human to live a life that is created by God, while culture is habits of the way of life for humans from the results of creativity, perception, and passion given by God. ${ }^{32}$

The diverse religions and cultures in Indonesia often cause conflicts and divisions. Society oftentimes claims that religion triggers differences that lead to conflict. It is said that people, in general, are mostly oriented towards fulfilling their hedonistic needs, hence, they

\footnotetext{
${ }^{27}$ Kon. K. Madut, 2020, "Determinats of Early Marriage and Construction of Gender Roles in South Sudan, Journal of Black Studies, Vol 1, No 9, page 6, https://doi.org/10.1177/2158244020922974

${ }^{28}$ Rachel Kidman, 2018, "Child Marriage and Intimate Partner Violence: a Comparative Study of 34 Countries", International Journal of Epidemiology, Vol 46, No 2, page 1-14, doi: 10.1093/ije/dyw225.

${ }^{29}$ Gina Lestari, 2015, Bhinneka Tunggal lka : Khasanah Multikultural Indonesia Di Tengah Kehidupan SARA, Jurnal IImiah Pendidikan Pancasila dan Kewarganegaraan, Vol. 28 No.1, page 31.

${ }^{30}$ Kusumohamidjojo, Kebhinekaan Masyarakat Indonesia, Jakarta : PT. Gramedia Widiasarana, 2000, page 45.

${ }^{31}$ Ridwan, Problematika Kearagaman Budaya dan Alternatif Pemecahan, Journal Article Madaniyah, Vol 2 Edisi 9, 2015, page 254.

${ }^{32}$ Laode Monto Bauto, 2014, Perspektif Agama dan Kebudayaan Dalam Kehidupan Masyarakat Indonesia, Jurnal Pendidikan IImu Sosial, Vol 23 No 2, page 24 .
}

violate religious teachings that they deem prohibiting them from doing things that they desire, and they rationalize the irrational act with intellectual social justifications. ${ }^{33}$ Every religious community will live a life in accordance with the beliefs and mandates of their respective religions. It is undeniable that this will lead to conflict across religions. Not only limited to religion, but this also applies to differences in culture or customs of each group.

From the life of the Indonesian people that is inseparable from the aspects of religion and culture, everything that becomes habits and rules in society cannot be separated from the influence of custom and religion. This gender inequality does not only occur due to traditions and beliefs held by people with different understandings but also due to the applicable systems and regulations. This results in the planting of an understanding in society that women are in a lower position than men and it is not surprising that there are policies that are not in favour of women. ${ }^{34}$ To take a case in point, a policy with regards to the minimum age requirements for marriage in Law Number 1 of 1974 on Marriage.

Article 7 paragraph 1 of Law Number 1 of 1974 on Marriage provides that the age recognized by the state to enter into marriage is if the man has reached the age of 19 and the woman has reached the age of 16 . It is not necessarily the case, since the minimum age requirement for marriage can still be dispensed by the court. The minimum age requirement is considered to reflect special discrimination for women and is considered to legalize child marriage because the minimum age limit for women is lower than for men. It can be said that the legal standard of marriage for women is considered very young. This condition is exacerbated by the provisions of Article 7 paragraph 2 of Law Number 1 of 1974 on Marriage that allows deviation from the minimum age stipulated in marriage by requesting dispensation to the court or other official. $^{35}$

The provision of the minimum age for marriage in Indonesia has caused many polemics in the community. However, there is hope as the House of Representatives ratifies the amendment to norms

\footnotetext{
${ }^{33}$ Ibid

${ }^{34}$ Tilaar dan Riant Nugroho, Kebijakan Pendidikan "Pengantar Untuk Memahami Kebijakan Pendidikan dan Kebijakan Pendidikan Sebaga Kebijakan Publik", Yogyakarta : Pustaka Belajar, 2012, page. 156

${ }^{35}$ Sonny Dewi Judiasih (et.al), 2018, "Women, Law and Policy: Child Marriage Practice Indonesia", Jurnal Notariil, Vol 3, No 1, page 51.
} 
related to the minimum age for marriage into law as contained in Article 7 of Law Number 16 of 2019 on Amendments to Law Number 1 of 1974 on Marriage. This is one of the efforts taken by the Indonesian government to minimize child marriage, as a form of Indonesia's participation as a member of the United Nations that requires the realization of gender equality as stated in the Sustainable Development Goals. The following table shows the changes in the minimum age for marriage in Indonesian Marriage Law.

\begin{tabular}{|c|c|}
\hline $\begin{array}{c}\text { Law Number 1 of 1974 on } \\
\text { Marriage }\end{array}$ & $\begin{array}{c}\text { Law Number 16 of 2019 on } \\
\text { Marriage }\end{array}$ \\
\hline \hline Article 7 Paragraph (1): & Article 7 Paragraph (1): \\
$\begin{array}{c}\text { A marriage can only be held if } \\
\text { the man reaches 19 years of } \\
\text { age and the woman reach the } \\
\text { age of 16. }\end{array}$ & $\begin{array}{c}\text { A marriage can only be held if } \\
\text { both the man and woman } \\
\text { reach the age of 19. } \\
\text { Article 7 Paragraph (2): } \\
\text { Article 7 Paragraph (2): } \\
\begin{array}{c}\text { In the case of deviations from } \\
\text { Paragraph (1), parents of either } \\
\text { party may request for a } \\
\text { dispensation from the Court or } \\
\text { legal age requirement set forth } \\
\text { in Paragraph (1), parents of } \\
\text { the man/woman may request } \\
\text { for dispensation from the Court } \\
\text { with very urgent reasons }\end{array} \\
\text { accompanied by sufficient } \\
\text { supporting evidence. }\end{array}$ \\
\hline
\end{tabular}

\section{The Request for Marriage Dispensation during Covid-19 Pandemic in Indonesia}

One of the most impacted aspects by the Covid-19 pandemic is, definitely, the economy. A huge number of workers underwent layoffs during this pandemic. This results in a general decrease in the workers' welfare and economic power. There are workers who are also parents who take shortcuts that they deemed are the best solution to help their economic problems during this pandemic, namely, marrying off their children at an early age. It is widely assumed that marrying off a child even at a young age is a solution and an escape point to the family's 'burden'. In addition, during this pandemic, the government closed schools and students had to learn from home, hence, teenagers or children have more time and freedom to interact with their environment since they do not have to spend all their time at school. Since they are not in school, they are more likely to interact outside the school, hence, causes the rise of dispensation for marriage minimum age requirement during this pandemic.

Article 1 Paragraph 5 of the Regulation of the Supreme Court of the Republic of Indonesia Number 5 of 2019 on Guidelines for Hearing Marriage Dispensation Application provides that Marriage
Dispensation is the granting of permission to marry a prospective husband/wife who is not yet 19 (nineteen) years of age to have a marriage.

Based on Article 6 of the Supreme Court Regulation Number 5 of 2019 on Guidelines for Hearing Marriage Dispensation Application, Parties who are entitled to apply for Marriage Dispensation are:

1. The party entitled to apply for a marriage dispensation is the parents;

2. In the event that the parents are divorced, the request for dispensation of marriage is still filed by both parents or one of the parents with custody of the child based on a court decision;

3. In the event that one of the parents has passed away or whose whereabouts is unknown, the application for dispensation of marriage is submitted by one of the parents;

4. In the event that both parents have passed away or been deprived of their power or whose whereabouts are unknown, the application for dispensation of marriage is submitted by the guardian of the child;

5. In the event the parent/guardian is absent, the application for dispensation shall be submitted by the attorney based on a power of attorney from the parent/guardian in accordance with the applicable regulations.

The administrative requirements for submitting marriage dispensation in accordance with Article 5 of the Supreme Court Regulation Number 5 of 2019 on Guidelines for Hearing Marriage Dispensation Applications include:

1. Administrative requirements for submitting applications for dispensation of marriage are:

a. Application letter;

b. Photocopy of Identity Card of both parents/guardians;

c. Photocopy of family card;

d. Photocopy of Identity Card or Child Identity Card and/or birth certificate

e. Photocopy of Identity Card or Child Identity Card and/or birth certificate of the prospective husband/wife; and 
f. Photocopy of the child's latest education certificate and/or reference letter from the attended school.

2. If the requirements as referred to in paragraph (1) letter $b$ to letter $f$ cannot be fulfiled, the dispensation application can use other documents that explain the identity and educational status of the child and the identity of the parents/guardians.

Even in the mids the Covid-19 pandemic, there are still request for marriage dispensation. Based on data obtained from the Application of the Case Tracking
Information System (Aplikasi Sistem Informasi Penelurusan Perkara/SIPP) of the Religious Courts in cities and regencies in West Java, it is noted that from January to August 2020, the applications for marriage dispensation in West Java have reached 5,507 cases. Based on the data from the application, it is found that in just a month, there are dozens of applications for marriage dispensation to the Religious Courts. This study focuses on child marriage couples who are Muslim who apply for a dispensation to the Religious Court, excluding those who carry out child marriage without requesting marriage dispensation. Thus, this study will only utilize and present data of marriage dispensation application from the Religious Court.

Table 1: Statistics of Marriage Dispensation Application at the Religious Courts in West Java Province in January December 2020

\begin{tabular}{|c|c|c|c|c|c|c|c|c|c|c|c|c|c|}
\hline No & City / Regency & Jan & Feb & Mar & Apr & May & Jun & Jul & Augst & Sep & Oct & Nov & Dec \\
\hline 1 & Cimahi City & 3 & 6 & 5 & 1 & 1 & 5 & 8 & 6 & 3 & 4 & 6 & 7 \\
\hline 2 & $\begin{array}{l}\text { Bandung Barat } \\
\text { Regency }\end{array}$ & 33 & 27 & 12 & 4 & 5 & 30 & 51 & 26 & 31 & 29 & 27 & 17 \\
\hline 3 & Bekasi Regency & 2 & 10 & 5 & 2 & - & 3 & 6 & 4 & 6 & 2 & 3 & 6 \\
\hline 4 & Bogor Regency & 52 & 59 & 47 & 3 & - & 33 & 36 & 45 & 32 & 15 & 28 & 20 \\
\hline 5 & Bandung Regency & 49 & 31 & 19 & 21 & 15 & 51 & 69 & 43 & 33 & 37 & 44 & 37 \\
\hline 6 & $\begin{array}{c}\text { Ciamis \& Pangandaran } \\
\text { Regency }\end{array}$ & 88 & 65 & 59 & 47 & 27 & 95 & 111 & 57 & 50 & 73 & 79 & 57 \\
\hline 7 & Cirebon Regency & 46 & 53 & 38 & 19 & 21 & 82 & 54 & 45 & 47 & 46 & 54 & 39 \\
\hline 8 & Cianjur Regency & 26 & 56 & 44 & 7 & 13 & 66 & 86 & 64 & 37 & 57 & 57 & 30 \\
\hline 9 & Garut Regency & 58 & 57 & 40 & 15 & 19 & 47 & 101 & 44 & 16 & - & - & - \\
\hline 10 & Indramayu Regency & 66 & 52 & 37 & 40 & 32 & 98 & 78 & 64 & 97 & 73 & 73 & 51 \\
\hline 11 & Karawang Regency & 18 & 12 & 16 & 13 & 4 & 19 & 35 & 21 & 36 & 10 & 27 & 3 \\
\hline 12 & Kuningan Regency & 44 & 24 & 31 & 21 & 16 & 67 & 63 & 21 & 23 & 29 & 28 & 22 \\
\hline 13 & Majalengka Regency & 39 & 23 & 39 & 13 & 13 & 56 & 69 & 32 & 50 & 38 & 47 & 25 \\
\hline 14 & Purwakarta Regency & 25 & 25 & 19 & 11 & 7 & 30 & 43 & 26 & 27 & 21 & 18 & 6 \\
\hline 15 & Subang Regency & 14 & 17 & 7 & 6 & 4 & 31 & 33 & 27 & 10 & 5 & 26 & 8 \\
\hline 16 & SuDistumi Regency & 18 & 16 & 18 & 3 & 1 & 23 & 54 & 36 & 19 & 25 & 24 & 15 \\
\hline 17 & Sumedang Regency & 60 & 14 & 22 & 9 & 9 & 62 & 99 & 36 & 42 & 48 & 51 & 29 \\
\hline 18 & Tasikmalaya Regency & 104 & 83 & 45 & 10 & 31 & 125 & 180 & 71 & 83 & 91 & 86 & - \\
\hline 19 & Bandung City & 27 & 24 & 5 & 1 & 9 & 24 & 35 & 26 & 25 & 9 & 24 & 9 \\
\hline 20 & Banjar City & 8 & 9 & 4 & 1 & 1 & 10 & 10 & 8 & 7 & 7 & 4 & 7 \\
\hline 21 & Bogor City & 14 & 7 & 12 & - & - & 9 & 5 & 2 & 4 & 7 & 3 & 3 \\
\hline 22 & Cirebon City & 5 & 6 & 2 & - & 5 & 7 & 7 & 3 & 2 & 8 & 3 & 5 \\
\hline 21 & Depok City & 14 & 17 & 5 & - & - & 10 & 13 & 5 & 6 & 10 & 1 & - \\
\hline 22 & SuDistumi City & 16 & 9 & 7 & - & - & 5 & 11 & 9 & 4 & 6 & 7 & 7 \\
\hline 23 & Tasikmalaya City & 32 & 28 & 7 & 7 & 15 & 32 & 36 & 9 & 29 & 18 & 22 & 13 \\
\hline \multirow[t]{2}{*}{24} & Bekasi City & 4 & 10 & 4 & - & 1 & 5 & 5 & 1 & 9 & 4 & 12 & 6 \\
\hline & & \multicolumn{7}{|c|}{ TOTAL } & \multicolumn{5}{|c|}{$\underline{8.276}$} \\
\hline
\end{tabular}


Table 2: Reasons for Filling A Marriage Dispensation Application

\begin{tabular}{|c|c|c|c|}
\hline No & Regions & Reasons & Sources \\
\hline 1 & Semarang & Pregnancy outside of marriage and economic factors. & www.ayosemarang.com \\
\hline 2 & Cianjur & $\begin{array}{l}\text { Poverty-stricken or economic factors and due to amendment of the } \\
\text { minimum age requirement in Law Number } 1 \text { of } 1974 \text { on Marriage. }\end{array}$ & www.pikiran-rakyat.com \\
\hline 3 & Indramayu & $\begin{array}{l}\text { Economic factors, a free-sex lifestyle that causes pregnancy outside of } \\
\text { marriage and environmental factors in the form of the assumption that } \\
\text { children are a burden on the family. }\end{array}$ & www.pikiran-rakyat.com \\
\hline 4 & Solo & Pregnancy outside of marriage. & \\
\hline 5 & Purwakarta & $\begin{array}{l}\text { Social factors on parents' anxiety of free sex lifestyle and the influence } \\
\text { of changes to the minimum age requirement in Law Number } 1 \text { of } 1974 \\
\text { on Marriage. }\end{array}$ & www.jabarnews.com \\
\hline 6 & Sukoharjo (Regency) & $\begin{array}{l}\text { Pregnancy outside of marriage and parents' anxiety of free sex } \\
\text { lifestyle. }\end{array}$ & www.solopos.com \\
\hline 7 & Wonogiri & Pregnancy outside of marriage & www.liputan6.com \\
\hline 8 & Wates & $\begin{array}{l}\text { Pregnancy outside of marriage and due to amendment of the minimum } \\
\text { age requirement in Law Number } 1 \text { of } 1974 \text { on Marriage. }\end{array}$ & news.harianjogja.com \\
\hline 9 & Jepara & $\begin{array}{l}\text { Pregnancy outside of marriage and due to amendment of the minimum } \\
\text { age requirement in Law Number } 1 \text { of } 1974 \text { on Marriage. }\end{array}$ & jateng.antaranews.com \\
\hline 10 & Bojonegoro & Pregnancy outside of marriage. & Blokbojonegoro.com \\
\hline 11 & Muara Sabak & Parents' anxiety of free sex lifestyle and due to dropping out of school. & Metrojambi.com \\
\hline
\end{tabular}

Based on the table above, the application for marriage dispensation submitted to religious courts in West Java is ranked based on the number of requests. It can be seen that the highest application for marriage dispensation is requested by applicants from Tasikmalaya Regency. The Religious Court of Tasikmalaya recorded 909 applications by November 2020. Then, the second position is held by the Religious Court of Ciamis, which has a joint jurisdiction of the Ciamis Regency and Pangandaran Regency with the number 808 application for marriage dispensation by December 2020. The third position for mostsubmitted application for marriage dispensation is the Religious Court of Cirebon Regency, with 544 applications. From the table, it is known that requests for dispensation of marriage are mostly submitted by people in regency areas.

The major reasons for filing a marriage dispensation at the Religious Courts are due to economic factors, limited employment, educational factors, customs, parental concerns, and unwanted pregnancies.

From the table above, the most common reasons that are requested for marriage dispensation and accepted by the court is because of pregnancy outside of marriage.

From the table comparing marriage dispensation statistics in provinces in Indonesia, it can be seen that the high rate of marriage dispensation during the

Table 3: Comparison of Marriage Dispensation Statistics of Provinces in Indonesia January - September 2020

\begin{tabular}{|c|c|c|c|}
\hline No & Provinces & City/Regency & Total \\
\hline \hline 1. & Central Java & Semarang City & 226 \\
\hline 2. & East Java & Bondowoso Regency & 1.077 \\
\hline 3. & Central Borneo & Kapuas Regency & 163 \\
\hline 4. & South Borneo & Banjarbaru City & 136 \\
\hline 5. & Aceh & Sigli City & 172 \\
\hline 6. & Jambi & Tanjung Jabung Timur Regency & 61 \\
\hline 7. & West Sumatera & Padang City & 39 \\
\hline 8. & North Sumatera & Medan City & \\
\hline
\end{tabular}


Table 4: Marriage Dispensation Application in Region with Most Covid-19 Cases

DKI Jakarta is currently an area with most new Covid-19 cases after Surabaya. The reality, however, shows that the applications for marriage dispensation are very high. The following table contains data on applications for marriage dispensation in Jakarta and Surabaya area.

Jakarta Province

\begin{tabular}{|c|c|c|c|c|c|c|c|c|c|c|c|c|c|}
\hline City & Jan & Feb & Mar & Apr & May & Jun & Jul & Aug & Sep & Oct & Nov & Dec & Total \\
\hline \hline Central Jakarta & 20 & 19 & 7 & - & - & 16 & 16 & 9 & 5 & 14 & 9 & 6 & 121 \\
\hline West Jakarta & 20 & 10 & 9 & - & 1 & 3 & 14 & 10 & 7 & 8 & 5 & 1 & 88 \\
\hline East Jakarta & 22 & 26 & 19 & 3 & 5 & 16 & 16 & 17 & 14 & 10 & 9 & 7 & 164 \\
\hline South Jakarta & 14 & 7 & 5 & - & 3 & 22 & 20 & 9 & 7 & 5 & 6 & 2 & 100 \\
\hline North Jakarta & 23 & 18 & 10 & 3 & - & 9 & 21 & 12 & 5 & 7 & 10 & 9 & 127 \\
\hline TOTAL & \multicolumn{10}{|c|}{} \\
\hline
\end{tabular}

East Java Province (Surabaya)

\begin{tabular}{|c|c|c|c|c|c|c|c|c|c|c|c|c|}
\hline City & Jan & Feb & Mar & Apr & May & Jun & Jul & Aug & Sep & Oct & Nov & Des \\
\hline \hline Surabaya & 47 & 33 & 36 & 16 & 12 & 43 & 55 & 4 & 38 & 40 & 47 & 35 \\
\hline
\end{tabular}

Covid-19 pandemic does not only occur in West Java, but also in other provinces such as Central Java, East Java, and areas from outside Java Island. There has also been an increase in the number of applications for marriage dispensation during January-June 2020. The statistics on the table are only samples from one city/regency shown in each province, not the coverage of the total number of marriage dispensations in 1 (one) province as a whole. Even so, the marriage dispensation rate displayed in the table is considered high even though it only shows the statistics in one city/regency in a province. The comparison of statistics on marriage dispensation in various provinces confirms that applications for marriage dispensation are more in regency areas, that are generally far from the hustle and bustle of urban areas. From the table comparing marriage dispensation statistics in provinces in Indonesia, it can be seen that the high rate of marriage dispensation during Covid-19 pandemic does not only occur in West Java, but also in other provinces such as Central Java, East Java, and areas from outside Java Island. There has also been an increase in the number of applications for marriage dispensation during January-December 2020.

The statistics on the table are only samples from one city/regency shown in each province, not the coverage of the total number of marriage dispensations in 1 (one) province as a whole. Even so, the marriage dispensation rate displayed in the table is considered high even though it only shows the statistics in one city/regency in a province. The comparison of statistics on marriage dispensation in various provinces confirms that applications for marriage dispensation are more in regency areas, that are generally far from the hustle and bustle of urban areas.

Currently, the Religious Courts have received a surge in applications for marriage dispensation. The Covid-19 outbreak that has hit Indonesia is the factor that increases marriage dispensation applications, as it rises the practice of marriage.

The statistics on the above table indicates that since the Covid-19 pandemic began to spread in Indonesia from January to December, the Jakarta Religious Court recorded 600 cases of applications for marriage dispensation. In addition, the Surabaya Religious Court has received 406 requests for marriage dispensation, even though from the statistics obtained in the Case Tracking Information System (SIPP) Application, the Surabaya Religious Court received only 182 applications of marriage dispensation in this period last year. In 2020, the request for marriage dispensation has increased compared to the previous year.

Basically, the equality of marriage age to 19 years for men and women is expected to be an effort to minimize child marriage in Indonesia. However, the existence of exceptions through dispensation efforts makes the age requirement for marriage still be deviated, so that gender equality, which is expected to minimize child marriages above, cannot be realized or cannot be carried out as desired.

If we want to realize the provisions for equality of age for marriage as an effort to minimize child 
Table 5: Comparison of Minimum Age Requirement and Practices of Applying Marriage Dispensation in Several Countries

\begin{tabular}{|c|c|c|}
\hline Country & Minimum Age (Legally) & $\begin{array}{l}\text { Exceptions to the legal age of marriage - in special } \\
\text { circumstances and/or with third-party consent required }\end{array}$ \\
\hline Cambodia & $\begin{array}{c}18 \text { for girls and } 20 \text { for boys (Law on Marriage and } \\
\text { Family 1989), or } 18 \text { for girls and boys (Civil Code of } \\
\text { Cambodia 2007) }\end{array}$ & $\begin{array}{c}16 \text { if he or she wishes to marry and has parental/guardian } \\
\text { consent and if the other party is at least } 18 \\
\text { In the case of pregnancy if one or both parties are under } 18 \text {, } \\
\text { with parental/guardian consent or under general } \\
\text { guardianship consent if the marriageable party has the } \\
\text { minimum capacity required }\end{array}$ \\
\hline Malaysia & $\begin{array}{l}21 \text { for girls and boys in the case of non-Muslim } \\
\text { marriages; } 16 \text { for girls in the case of Muslim } \\
\text { marriages } \\
\text { Note: Muslim marriages must have prior consent } \\
\text { from the minister (religious authority) in the state of } \\
\text { residence }\end{array}$ & $\begin{array}{l}18 \text { with parental consent in the case of non-Muslim } \\
\text { marriages } \\
16 \text { for girls with the permission of a chief minister and with } \\
\text { parental consent in the case of non-Muslim marriages } \\
\text { Under } 16 \text { for girls with the permission of a sharia court } \\
\text { (Muslim marriages) }\end{array}$ \\
\hline Maldives & 18 for girls and boys & $\begin{array}{l}\text { Under } 18 \text { with permission from the Registrar of Marriages, } \\
\text { granted at long consideration }\end{array}$ \\
\hline Thailand & 21 for girls and boys & $\begin{array}{l}\text { Under } 21 \text { for boys and girls with parental consent, or under } \\
\qquad 17 \text { with a court order }\end{array}$ \\
\hline Tuvalu & 21 for girls and boys & $\begin{array}{l}16 \text { with the father's consent if possible, or the mother's, } \\
\text { guardian's or a Registrar-General's consent. }\end{array}$ \\
\hline Afganistan & 16 for girls and 18 for boys & 15 for girls with the permission of her father or a judge \\
\hline Iran & $\begin{array}{c}8 \text { years, } 9 \text { months for girls ( } 9 \text { lunar years), i.e. the } \\
\text { age of puberty under sharia law; } 14 \text { years, } 7 \text { months } \\
\text { for boys ( } 16 \text { lunar years) }\end{array}$ & $\begin{array}{c}\text { Marriage prior to puberty with permission from the } \\
\text { parents/guardian and if considered proper by the Mariage } \\
\text { Registrar }\end{array}$ \\
\hline Papua New Guinea & 16 for girls and 18 for boys & 14 for girls and 16 for boys with a court order \\
\hline The Philippines & $\begin{array}{l}21 \text { for girls and boys; age of puberty (approx. 15) for } \\
\text { girls and } 15 \text { for boys in the case of Muslim marriages }\end{array}$ & $\begin{array}{c}\text { Under } 18 \text { with parental consent or court order } \\
12 \text { for girls (in the case of Muslim marriages) with Sharia } \\
\text { court order }\end{array}$ \\
\hline Timor Leste & 17 for girls and boys & $\begin{array}{c}16 \text { with parents or guardian consent or with authorization } \\
\text { from the civil registrar }\end{array}$ \\
\hline
\end{tabular}

\#Sonny Dewi Judiasih, 2018, Perkawinan Bawah Umur di Indonesia, Beserta Perbandingan Usia Perkawinan dan Praktik Perkawinan Bawah Umur di Beberapa Negara, Bandung : Refika.

marriages in Indonesia, then the provisions regarding dispensation for marriage must be set aside, so that there is no practice of marriage in Indonesia. In addition to setting aside dispensation, another thing that can be done is by imposing fines or penalties for perpetrators of child marriages.

Generally, all developing countries are worried about the development of child marriage that continues to increase in their respective countries. This is a manifestation of human rights violations and the failure to achieve the aims and objectives of gender equality.

Below is a table with regards to comparisons of the minimum age requirement for marriage and the practice of applying exception or marriage dispensation in several countries.

\section{CONCLUSION}

1. The government's efforts to address the issue of gender inequality in terms of the age of marriage in Indonesia can be seen on Article 7 of Law Number 16 of 2019 on Amendments to Law Number 1 of 1974 on Marriage. This is one of the efforts taken by the Indonesian government to minimize child marriage, as a form of Indonesia's participation as a member of the United Nations that requires the realization of gender equality as stated in the Sustainable Development Goals.

2. During the Covid-19 pandemic, applications for marriage dispensation in Indonesia indicated a sharp increase. This means that the application for marriage dispensation is unaffected by the Covid-19 pandemic situation. The existence of exceptions through dispensation efforts makes the requirements for the age of marriage can still be deviated, so that gender equality, which is expected to minimize child marriages, cannot be realized or cannot be carried out as desired. If we want to realize the provisions for equality of age for marriage as an effort to minimize child 
marriages in Indonesia, then the provisions regarding dispensation for marriage must be set aside, so that there is no practice of child marriage in Indonesia. In addition to setting aside dispensation, another thing that can be done is by imposing fines or penalties for perpetrators of child marriages.

\section{REFERENCES}

Arrabide A (2013) Research Paper Child Marriage in South Asia. Available at https://www.reproductiverights.org/sites/ crr.civicactions.net/files/documents/ChildMarriage_BriefingPaper Web.pdf (accessed 25 September 2020).

Arthur M, Earle A, Raub A, Vincent I, Atabay E, Latz I, Kranz G, Nandi A, Hermann J, (2017) Child Marriage Laws Around The World: Minimum Marriage Age, Legal Exceptions, and Gender Disparities. Journal of Women, Politics \& Policy. 39 (1): pp 51-74. https://doi.org/10.1080/1554477X.2017.1375786

Azra A (2008) Kajian Tematik Al-Qur'an tentang Kemasyarakatan. Bandung : Angkasa : p 315

Bauto LM (2014) Perspektif Agama dan Kebudayaan Dalam Kehidupan Masyarakat Indonesia. Jurnal Pendidikan IImu Sosial. 23(2): pp 11-25. https://doi.org/10.17509/jpis.v23i2.1616

Bielska E (2015) Gender As A Category Entangled In The Matrix Of Power And Gender Resistance Potential. Journal Of Gender and Power. 3(1): pp 103-111

Cusack S and Pusey L (2013) CEDAW And The Rights To NonDiscrimination And Equality. Melbourne Journal of International Law. 14(1): pp 1-39

Dhatt R, Thompson K, Lichtensrein D, Ronsin K, and Wilkins K (2017) The Time is Now - a Call to Action for Gender Equality in Global Health Leadership. Global health, Epidemiology and Genomics. 2: pp 1-4. https://doi.org/10.1017/gheg.2017.1

Ferror S (2009) Human Rights Advocacy on Gender Issues: Challenges and Opportunities. Journal of Human Rights. 1(1): p 83-100. https://doi.org/10.1093/ihuman/hup002

Fibrianto AS (2016) Kesetaraan Gender Dalam Lingkup Organisasi Mahasiswa Universitas Sebelas Maret Surakarta Tahun 2016, Jurnal Analisa Sosiologi 5(1): pp 10-27. https://doi.org/10.20961/jas.v5i1.18422

Frohmader C and Ortoleva S .2014. The Sexual and Reproductive Rights of Women and Girls With Disabilities. ICPD Beyond. 1: pp 1-17

Goonesekere S (2014) From Social Welfare To Human Rights For Girls A Path To Achieving Gender Equality.International Journal of Law in Context. 10 (4): pp 478-493. https://doi.org/10.1017/S1744552314000238

Hasanah U and Musyafak N (2017) Keterlibatan Perempuan dalam Pembangunan Politik. Gender and Politics. 12(3): pp 406-432. https://doi.org/10.21580/sa.v12i3.2080

Jayachandran S (2015) The Roots of Gender Inequality in Developing Countries. The Annual Review of Economic. 7: pp 63-88. https://doi.org/10.3386/w20380

Judiasih SD, Suparto S, Afriana A, and Yuanitasari D (2018) Women, Law and Policy: Child Marriage Practice Indonesia. Jurnal Notariil, 3(1): p 47-55 https://doi.org/10.22225/in.3.1.647.47-55
Judiasih SD (2018). Perkawinan Bawah Umur di Indonesia, Beserta Perbandingan Usia Perkawinan dan Praktik Perkawinan Bawah Umur di Beberapa Negara. Bandung : Refika

Judiasih SD, Rubiati B, Yuanitasari D, Salim EF, Safira L (2020) Efforts to Eradicate Child Marriage Practices in Indonesia : Towards Sustainable Development Goal. Journal of International Women's Studies. 21(6): pp 135-149

Kelsey CL (2015) Gender Inequality : Empowering Women. Journal of Legal Issues and Cases in Business. 3: pp 1-7

Kidman R (2018) Child Marriage and Intimate Partner Violence: a Comparative Study of 34 Countries. International Journal of Epidemiology. 46(2): pp. 1-14. https://doi.org/10.1093/ije/dyw225

Kusumohamidjojo (2000) Kebhinekaan Masyarakat Indonesia. Jakarta PT. Gramedia Widiasarana : p 45

Lestari G (2015) Bhinneka Tunggal Ika : Khasanah Multikultural Indonesia Di Tengah Kehidupan SARA. Jurnal Ilmiah Pendidikan Pancasila dan Kewarganegaraan. 28(1): pp 31-37. https://doi.org/10.17.977/jppkn.v28i1.5437

Madut KK (2020) Determinats of Early Marriage and Construction of Gender Roles in South Sudan. Journal of Black Studies. 1(9): pp $1-9$. https://doi.org/10.1177/2158244020922974

Mim SA (2017) Effects of Child Marriage on Girls education and Empowerment". Journal of Education and Learning, Vol 11 (1): $\mathrm{p}$ 12-13 https://doi.org/10.11591/edulearn.v11i1.5130

Odrowaz-Coates A (2015) Is Gender Neutrality A Post Human Phenomenon? The Concept of 'Gender Neutral' in Swedish Education. Journal Of Gender and Power. 3 (1): pp 114-133

Poczatkova B and Kribikova P (2017) Gender Inequality In The Field Of Science And Research. Journal Of International Studies. 10(1): pp 267-276. https://doi.org/10.14254/2071-8330.2017/10-1/19

Ridwan (2015) Problematika Kearagaman Budaya dan Alternatif Pemecahan. Journal Article Madaniyah. 5(2): p 254-270

Rumble L, Peterman A, Irdiana N, Triyana M, and Minnick E (2008) An Empirical Exploration of Female Child Marriage Determinants in Indonesia. BMC Public Health. 18 (407): pp 1-13. https://doi.org/10.1186/s12889-018-5313-0

Sekine K and Hodgkin ME (2017) Effect Of Child Marriage On Girls's School Dropout In Nepal: Analysis Of Data From The Multiple Indicator Cluster Survey 2014. PLoS ONE, 12(7): pp 1-13. https://doi.org/10.1371/journal.pone.0180176

Shahstri A (2016) Gender Inequality and Women Discrimination. IOSR Journal of Humanities and Social Science. 19(11): pp 27-30. https://doi.org/10.9790/0837-191172730

Shaumi F and Aushafina A (2018) Gender Equality Through Sustainable Development Goals: The Case of Timor Leste. Jurnal Global \& Strategis. 12(2): p 81-90. https://doi.org/10.20473/jgs.12.2.2018.81-90

Soekanto S and Mamudji S (2001) Penelitian Hukum Normatif "Suatu Tinjauan Singkat". Jakarta : Rajawali Pers

Stuart A (2015) Right Freedom of Religion: A Gendered Difference. Journal Of Gender and Power. 3(1): p 25-66

Tilaar and Nugroho R (2012) Kebijakan Pendidikan "Pengantar Untuk Memahami Kebijakan Pendidikan dan Kebijakan Pendidikan Sebagai Kebijakan Publik". Yogyakarta : Pustaka Belajar : p 156

Received on 12-09-2021

Accepted on 02-11-2021

Published on 09-12-2021

\section{https://doi.org/10.6000/1929-4409.2021.10.177}

(c) 2021 Judiasih et al.; Licensee Lifescience Global.

This is an open access article licensed under the terms of the Creative Commons Attribution License (http://creativecommons.org/licenses/by/4.0/) which permits unrestricted use, distribution and reproduction in any medium, provided the work is properly cited. 